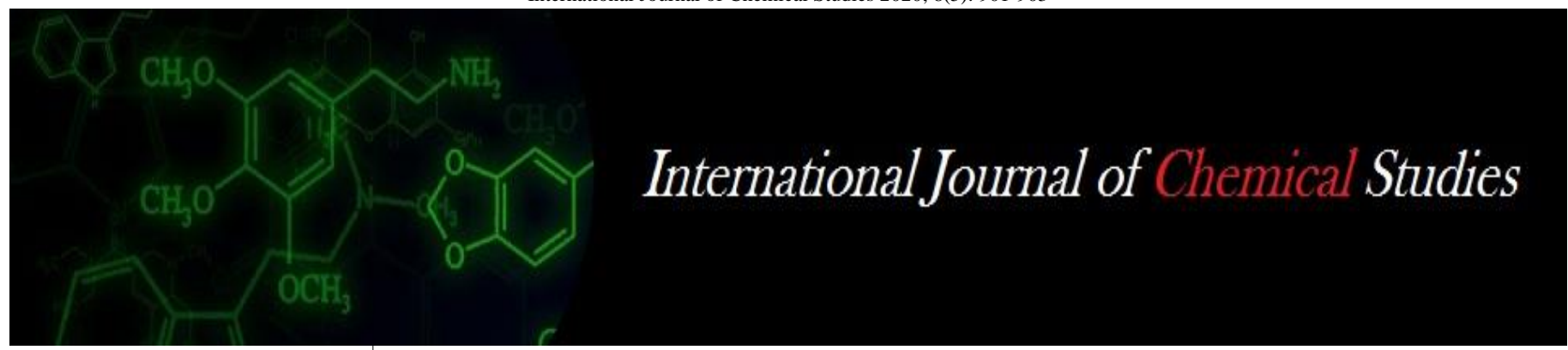

P-ISSN: 2349-8528

E-ISSN: 2321-4902

www.chemijournal.com

IJCS 2020; 8(5): 901-903

(C) 2020 IJCS

Received: 15-06-2020

Accepted: 28-07-2020

\section{Sanii Lanah}

Institute of Biotechnology,

Professor Jayashankar

Telangana State Agricultural

University, Rajendranagar,

Hyderabad, Telangana, India

Vanisri S

Institute of Biotechnology,

Professor Jayashankar

Telangana State Agricultural

University, Rajendranagar,

Hyderabad, Telangana, India

\section{Abdul Fiyaz R}

ICAR-Indian Institute of Rice

Research (ICAR-IIRR),

Rajendranagar, Hyderabad,

Telangana, India

\section{Sreedhar Mulinti}

MFPI-Quality Control Lab,

Professor Jayashankar

Telangana State Agricultural

University, Rajendranagar,

Hyderabad, Telangana, India

\section{Durga Rani CHV}

Institute of Biotechnology,

Professor Jayashankar

Telangana State Agricultural

University, Rajendranagar,

Hyderabad, Telangana, India

\section{Ramesh T}

Department of Physiology, College of Agriculture, Professor

Jayashankar Telangana State Agricultural University,

Rajendranagar, Hyderabad,

Telangana, India

\section{Corresponding Author:}

\section{Sanii Lanah}

Institute of Biotechnology,

Professor Jayashankar

Telangana State Agricultural

University, Rajendranagar,

Hyderabad, Telangana, India

\section{Correlation studies in magic indica plus population and Indian rice germplasm}

\author{
Sanii Lanah, Vanisri S, Abdul Fiyaz R, Sreedhar Mulinti, Durga Rani \\ CHV and Ramesh T
}

DOI: $\underline{\text { https://doi.org/10.22271/chemi.2020.v8.i5m.10411 }}$

\begin{abstract}
One hundred and two MAGIC indica plus lines, one hundred and four rice accessions, along with four standard checks of rice (Oryza sativa L.) were evaluated during Kharif 2017 to study the nature and extent of correlation among yield and yield attributing characters viz., days to 50 per cent flowering, plant height, number of productive tillers per plant, panicle length, number of filled grains per panicle, number of grains per panicle, spikelet fertility, thousand-grain weight, grain yield per plant. The results revealed that grain yield plant per plant to be positively and significantly associated with with number of filled grains per panicle $\left(\mathrm{r}_{\mathrm{p}}=0.657 * * ; \mathrm{r}_{\mathrm{g}}=0.665\right)$, spikelet fertility $\left(\mathrm{r}_{\mathrm{p}}=0.301 * * ; \mathrm{r}_{\mathrm{g}}=0.321\right)$, number of productive tillers per hill $\left(r_{p}=0.153^{* * ;} r_{g}=0.068\right)$, panicle length $\left(r_{p}=0.133^{* *}, r_{g}=0.114\right)$ indicating importance of these traits as selection criteria in yield improvement programmes.
\end{abstract}

Keywords: Rice, MAGIC indica plus population, Indian rice germplasm, yield, correlation

\section{Introduction}

Rice (Oryza sativa L.) is one of the pivotal staple cereal crops feeding more than half of the world population. In view of the growing population, the basic objective of the plant breeders would always be towards yield improvement in staple food crops. It is estimated that the demand for rice will be 121.2 million tonnes by the year 2030, 129.6 million tonnes by the year 2040 and 137.3 million tonnes by the year 2050 (Anonymous, 2015) ${ }^{[2]}$. The grain yield is a complex trait, quantitative in nature and a combined function of several constituent traits. Consequently, selection for yield per se may not be much satisfying unless other yield component traits are taken into consideration (Satheeshkumar and Saravanan, 2012) [13]. Understanding of correlation between yield and yield components are fundamental to find out strategies for plant selection (Hasan et al., 2011) ${ }^{[7]}$. The present study was, therefore, undertaken to understand the character associations in rice accessions for yield improvement.

\section{Materials and Methods}

The present study comprised of 102 MAGIC indica plus lines, 104 rice accessions and 4 checks, the experiment were carried out at the College farm, College of Agriculture, PJTSAU, Rajendranagar, Hyderabad during kharif, 2017. The experiment trial was laid out in Alpha Lattice Design with 3 replications. Each entry was planted in 4 rows with a spacing of $15 \times 15$ $\mathrm{cm}^{2}$. Data on the basis of 5 randomly taken competitive plants excluding borders were recorded on seven quantitative characters viz., plant height, number of productive tillers per plant, panicle length, number of filled grains per panicle, number of grains per panicle, spikelet fertility, thousand-grain weight, grain yield per plant while days to fifty percent flowering was recorded on a whole plot basis. Correlation coefficients were calculated at genotypic and phenotypic level using the formulae suggested by Falconer (1964) ${ }^{[6]}$.

\section{Results and Discussion}

The estimates of simple correlation coefficients (phenotypic and genotypic) computed between eight characters under study are presented in Table-1 and Table-2.

In the present study, grain yield per plant possessed positive and highly significant correlation with number of filled grains per panicle $\left(r_{p}=0.657 * * ; r_{g}=0.665\right)$, spikelet fertility $\left(r_{p}=\right.$ $\left.0.301 * * ; r_{\mathrm{g}}=0.321\right)$, number of productive tillers per hill $\left(\mathrm{r}_{\mathrm{p}}=0.153^{* *} ; \mathrm{r}_{\mathrm{g}}=0.068\right)$, panicle 
length $\left(r_{p}=0.133^{* *}, r_{g}=0.114\right)$. These findings were also corroborated by Ekka et al. (2011) ${ }^{[5]}$, Lakshmi et al. (2014) ${ }^{[11]}$, Hossain et al. (2015) ${ }^{[8]}$, Babu et al. (2012) ${ }^{[3]}$, Anis et al., (2016) [1], Kumar et al. (2018) [10], Swapnil et al. (2020) ${ }^{[14]}$, Parimala et al. (2020) ${ }^{[12]}$ and Khan et al. (2020) [9]. It indicated that grain yield can be increased whenever there is an increase in characters that showed positive and significant association with grain yield. Hence, these characters can be considered as criteria for selection for higher yield as these were mutually and directly associated with yield. On contrary, plant height showed negative and significant correlation associated with grain yield per plant $\left(\left(r_{p}=-0.103^{*} ; r_{g}=-\right.\right.$ 0.104). Negative correlation coefficient of plant height with grain yield indicated that in general, tall genotypes were low yielders due to accumulation of photosynthates in vegetative parts as compared to reproductive parts (i.e. seed formation and grain filling) and were lodging susceptible (Zahid et al.,
2006) ${ }^{[16]}$. Negative and non-significant associated of 1000 grain weight with grain yield per plant $\left(r_{p}=0.039 ; r_{g}=-0.023\right)$. Similar kind of negative and non-significant association of phonological characters with grain yield per plant was reported earlier for observations on 1000 grain weight (Babu et al. 2012) ${ }^{[3]}$.

The results revealed that the genotypic correlation coefficients in most cases were higher than their phenotypic correlation coefficients indicating the association was largely due to genetic reason (Bhattacharyya et al. 2007) ${ }^{[4]}$. However, the phenotypic correlation coefficients in some cases were higher than their genotypic correlation, which indicates the suppressing effect of the environment that can alter the expression of characters at the phenotypic level. Our finding is in agreement with the previous result in early maturing rice presented by Tiwari et al., (2019) ${ }^{[15]}$.

Table 1: Estimation of phenotypic correlation coefficients between yield and yield related attributes in 210 rice accessions

\begin{tabular}{|c|c|c|c|c|c|c|c|c|}
\hline Character & $\begin{array}{c}\text { Days to } \\
\mathbf{5 0 \%} \\
\text { Flowering }\end{array}$ & $\begin{array}{c}\text { Plant } \\
\text { Height } \\
(\mathbf{c m})\end{array}$ & $\begin{array}{c}\text { No. of } \\
\text { Productive } \\
\text { Tillers/ Hill }\end{array}$ & $\begin{array}{c}\text { Panicle Length } \\
(\mathbf{c m})\end{array}$ & $\begin{array}{c}\text { No. of Filled } \\
\text { Grains/Panicle }\end{array}$ & $\begin{array}{c}\text { Spikelet } \\
\text { Fertility } \\
(\%)\end{array}$ & $\begin{array}{c}\text { 1000 Grain } \\
\text { Weight (g) }\end{array}$ & $\begin{array}{c}\text { Grain } \\
\text { Yield/Plant (g) }\end{array}$ \\
\hline Days to 50\% flowering & 1.000 & $0.140^{* *}$ & 0.074 & -0.055 & 0.042 & $-0.175^{* *}$ & $-0.213^{* *}$ & -0.006 \\
\hline Plant height (cm) & & 1.000 & 0.069 & $0.369^{* *}$ & -0.005 & $-0.176^{* *}$ & 0.014 & $-0.103^{*}$ \\
\hline No. of productive tillers/ Hill & & & 1.000 & 0.006 & 0.003 & $-0.103^{*}$ & -0.059 & $0.153^{* *}$ \\
\hline Panicle length (cm) & & & & 1.000 & $0.278^{* *}$ & 0.002 & $0.166^{* *}$ & $0.133^{* *}$ \\
\hline No. of filled grains/ Panicle & & & & & 1.000 & $0.500^{* *}$ & -0.094 & $0.657^{* *}$ \\
\hline Spikelet Fertility & & & & & & 1.000 & 0.010 & $0.301^{* *}$ \\
\hline 1000 grain weight (g) & & & & & & & 1.000 & 0.039 \\
\hline Grain yield/Plant (g) & & & & & & & & \\
\hline
\end{tabular}

** Significant at 1 per cent level * Significant at 5 per cent level

Table 2: Estimation of genotypic correlation coefficients between yield and yield related attributes in 210 rice accessions

\begin{tabular}{|c|c|c|c|c|c|c|c|c|}
\hline Character & $\begin{array}{c}\text { Days to } 50 \% \\
\text { flowering }\end{array}$ & $\begin{array}{l}\text { Plant } \\
\text { height } \\
(\mathbf{c m})\end{array}$ & $\begin{array}{c}\text { No. of } \\
\text { productive } \\
\text { tillers/ Hill }\end{array}$ & $\begin{array}{c}\text { Panicle length } \\
(\mathrm{cm})\end{array}$ & $\begin{array}{l}\text { No. of filled } \\
\text { grains/panicle }\end{array}$ & $\begin{array}{c}\text { Spikelet } \\
\text { fertility (\%) }\end{array}$ & $\begin{array}{l}1000 \text { grain } \\
\text { weight (g) }\end{array}$ & $\begin{array}{c}\text { Grain } \\
\text { yield/Plant (g) }\end{array}$ \\
\hline Days to $50 \%$ flowering & 1.000 & 0.158 & 0.056 & -0.098 & 0.032 & -0.207 & -0.273 & -0.013 \\
\hline Plant height $(\mathrm{cm})$ & & 1.000 & 0.085 & 0.451 & -0.005 & -0.200 & 0.015 & -0.104 \\
\hline No. of productive tillers/ Hill & & & 1.000 & -0.057 & -0.105 & -0.195 & -0.197 & 0.068 \\
\hline Panicle length $(\mathrm{cm})$ & & & & 1.000 & 0.234 & -0.075 & 0.131 & 0.114 \\
\hline No. of filled grains/ Panicle & & & & & 1.000 & 0.494 & -0.193 & 0.665 \\
\hline Spikelet fertility & & & & & & 1.000 & -0.041 & 0.321 \\
\hline 1000 grain weight $(\mathrm{g})$ & & & & & & & 1.000 & -0.023 \\
\hline Grain yield/Plant $(\mathrm{g})$ & & & & & & & & 1.000 \\
\hline
\end{tabular}

** Significant at 1 per cent level * Significant at 5 per cent level

\section{Acknowledgements}

The authors would like to thank the Director IBT, Chairman and members for their support on conducting research activities, ICAR for PhD seat, Ministry of Tribal affairs for fellowship, and PJTSAU, Telangana for providing the facilities and encouragement.

\section{References}

1. Anis GB, EL-Namaky RA, AL-Ashkar IM, Barutçular C, El Sabagh A. Yield potential and correlation analysis of some rice hybrids for yield and its component traits. Journal of Animal \&Plant Sciences. 2016;30(2):4748-57.

2. Anonymous. CRRI Vision 2050. Central Rice Research Institute. Indian Council of Agricultural Research, Cuttack (Odisha), India, 2015, 753006.

3. Babu VR, Shreya K, Dangi KS, Usharani G, Shankar AS. Correlation and path analysis studies in popular rice hybrids of India. International Journal of Scientific and Research Publications. 2012; 2(3):1-5.
4. Bhattacharyya R, Roy B, Kabi MC, Basu AK. Character association and path analysis of seed yield and its attributes in rice as affected by bio-inoculums under tropical environment. Tropical Agricultural Research and Extension. 2007; 10:23-8.

5. Ekka RE, Sarawgi AK, Kanwar RR. Correlation and path analysis in traditional rice accessions of Chhattisgarh. Journal of rice research. 2011;4(1):11-8.

6. Falconer DS. Introduction to quantitative genetics. Pearson Education India, 1996.

7. Hasan MJ, Kulsum MU, Akter A, Masuduzzaman AS, Ramesha MS. Genetic variability and character association for agronomic traits in hybrid rice (Oryza sativa L.). Bangladesh Journal of Plant Breeding and Genetics. 2011; 24(1):45-51.

8. Hossain S, Haque M, Rahman J. Genetic variability, correlation and path coefficient analysis of morphological traits in some extinct local Aman rice (Oryza sativa L). Rice Research: Open Access, 2015. 
9. Khan R, Senapati BK, Sangeeta PL, Ahammed SS. Correlation and path analysis studies in recombinant inbred lines (F8) of Langulmota/Sambamahsuri derivatives. Journal of Pharmacognosy and Phytochemistry. 2020; 9(2):218-23.

10. Kumar S, Chauhan MP, Tomar A, Kasana RK, Kumar N. Correlation and path coefficient analysis in rice (Oryza sativa L.). The Pharma Innovation Journal. 2018; 7(6):20-6.

11. Lakshmi MV, Suneetha Y, Yugandhar G, Lakshmi NV. Correlation studies in rice (Oryza sativa L.). International Journal of Genetic Engineering and Biotechnology. 2014; 5(2):121-6.

12. Parimala K, Raju CS, Prasad AH, Kumar SS, Reddy SN. Studies on genetic parameters, correlation and path analysis in rice (Oryza sativa L.). Journal of Pharmacognosy and Phytochemistry. 2020; 9(1):414-7.

13. Satheeshkumar P, Saravanan K. Genetic variability, correlation and path analysis in rice (Oryza Sativa L.). International Journal of Current Research. 2012; 4(09):082-5.

14. Swapnil KP, Chakraborty M, Singh DN, Kumari P, Ekka JP. Genetic variability, correlation and path coefficient studies in F2 generation of rice (Orzya sativa L.). IJCS. 2020; 8(4):3116-20.

15. Tiwari DN, Tripathi SR, Tripathi MP, Khatri $\mathrm{N}$ and Bastola BR. Genetic variability and correlation coefficients of major traits in early maturing rice under rainfed lowland environments of Nepal. Advances in Agriculture, 2019.

16. Zahid MA, Akhter M, Sabar M, Manzoor Z, Awan T. Correlation and path analysis studies of yield and economic traits in Basmati rice (Oryza sativa L.). Asian J Plant Sci. 2006; 5(4):643-5. 